\title{
To the history of the Baltic-Ladoga connection
}

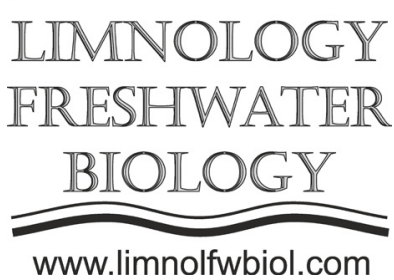

\author{
Dudanova V.I. ${ }^{1 *}$, Sheetov M.V. ${ }^{2}$, Biske Yu.S. ${ }^{1}$ \\ ${ }^{1}$ St. Petersburg State University, Institute of Earth Sciences, Universitetskaya Emb.7-9, St. Petersburg, 199034, Russia \\ ${ }^{2}$ Independent researcher
}

\begin{abstract}
In accordance with geochronological, lithological, palaeocriological and geomor phological data from the new key section on the right bank of the Neva River (the center of the hypothetical MgaTosna watershed) and the well-known "classical" section on the Nevsky Pyatachok, it was established that the flow from Lake Ladoga to the Baltic Sea in the southern part of the Karelian Isthmus at the site of the modern Neva Lowland took place in the Late Glacial time somewhat earlier than $11980 \mathrm{cal}$ yr. BP. After that, the flow along the (pre-) Neva has not been completely interrupted to date, and the transgressions of the Baltic palaeobasins has not penetrated into the territory of the Neva Lowland. There was probably a bifurcation of the flow from the Ladoga along the (pre-) Neva and the Heinijoki Strait in the central part of the Karelian Isthmus in the Late Pleistocene and the Early Holocene.
\end{abstract}

Keywords: the Ladoga Lake, the Neva River, palaeohydrology, the Late Pleistocene, the Holocene

\section{Introduction}

The problem of the Baltic-Ladoga connection - the time and place of its occurrence - has been discussed for more than 130 years. After J. Ailio (1915) and E. Hyyppa (1943) a hypothesis became popular (Malakhovsky et al., 1993) that the flow from Lake Ladoga to the Baltic Sea occurred from the Late Glacial time through the Heinijoki Strait in the central part of the Karelian Isthmus; so, the flow on the territory of the Neva Lowland and hydrological system LadogaNeva-Baltic recovered only after 3000 cal. BP, when maximum stage of the Ladoga transgression was reached. However, K.K. Markov (1934, p. 99) noted that after the separation of Ladoga from the Baltic Ice Lake (BIL), there was a bifurcation of the flow - both through the Heinijoki Strait and along the Neva, which was formed "long before the Ladoga transgression". N.N. Verzilin (1998) gave a number of arguments in favor of the existence of the Neva since the late glacial time. Where and how, after the fall of the BIL, a drain from Ladoga existed? Regressive contacts at the bottom of the peat at $19.0 \mathrm{~m}$ a.s.l. on the route of the hypothetical Heinijoki Strait (Nizhne-Osinovskoye bog) and at 12.3 $\mathrm{m}$ a.s.l. in the Neva Lowland (Ust-Tosnenskiy peat bed) have an age of 10400 and 10800 cal. BP respectively (Malakhovsky et al., 1993; Kuzmin et al., 1991). This fact records the establishment of subaerial conditions at the beginning of the Early Holocene. Some paleohydrological reconstructions (e.g., Vassiljev et al.,
2013) for about 12000 cal. BP reveal that Ladoga was connected to the the Gulf of Finland by narrow channel on the site of the modern Neva. The new data make it possible to clarify the age and mechanism of the BalticLadoga connection.

\section{Materials and metods}

In the course of field work in autumn 2019 two reference sections has been studied where late- and postglacial deposits in the upper stream expose, in the Nevsky Pyatachok area, and the middle stream of the Neva River, $2 \mathrm{~km}$ below the mouth of the Mga River, i.e. in the center of a hypothetical Mginsko-Tosnensky watershed. The last section was previously unknown. The sedimentary sequence, shape and relation of geological bodies, their connection with the modern and buried relief were examined here. Series of new ${ }^{14} \mathrm{C}$-data was obtained from selected organic material from late- and postglacial deposits in the Köppen Laboratory of SPSU. The age of radiocarbon data was calculated based on the OxCal 4.2 calibration program (IntCal 13 calibration curve, C. B. Ramsey, https://c14. arch.ox.ac.uk).

\section{Results and discussion}

The studied deposits form a section of a regionally widespread 10-meter terrace associated with

*Corresponding author.

E-mail address: varyanich1212@gmail.com (V.I. Dudanova)

(C) Author(s) 2020. This work is distributed under the Creative Commons Attribution 4.0 License. 
the Late Holocene Ladoga transgression. The section on the right bank of the Neva are exposed: glacial deposits (till) with a visible thickness of more than $3 \mathrm{~m}$, overlain by cross-bedding sands in the direction of the current flow of the Neva River; these sands of 0.1 to $1.0 \mathrm{~m}$ in thickness combine a shaft-shaped accumulative form. Up the section, cryoturbated sands and silts (up to 1.3 $\mathrm{m}$ in thickness) with wave-like and flaser bedding lay. Plant detritus from silts are of $11980 \pm 340$ cal. BP (LU$9625)$ in age. Above the silts, buried soil with the age of the roof $2190 \pm 90 \mathrm{cal}$. BP (LU-9008) developed at $8.5 \mathrm{~m}$ a.s.l. The soil is covered with washout by sands $(1.5 \mathrm{~m})$ with a climbing ripple structures defined as deposits of the Ladoga transgression. The radiocarbon age of wood remains at the bottom of these deposits is $3270 \pm 80$ cal. BP (LU-9624). Traces of a late glacial fluvial system, where the flow coincided with the current direction of the Neva, are also recorded in the section on the Nevsky Pyatachok. In this section, late glacial silty sand deposits with a climbing ripple structures were formed by a rapid flow in the direction of the Gulf of Finland, with low-thickness buried soil and peat $(1.5 \mathrm{~m})$ in their roof at $7 \mathrm{~m}$ a.s.l. Peat formation lasted from the beginning of the Early Holocene to the end of Subboreal time. The roof of the peat bog is at $8.5 \mathrm{~m}$ a.s.l. and is clearly washed out. The section is overlain by fine-grained sands of the Ladoga transgression with a thickness of about $1.5 \mathrm{~m}$. The direction and structure of cross-bedding sands with an age of about $11980 \mathrm{cal}$. $\mathrm{BP}$ indicates that their formation occurred in fluvial conditions with the flow in the direction of the modern course of the Neva River. This was associated with the emergence of the flow from the Ladoga Lake along the (pre-) Neva during the final drainage of the BIL. It was probably that the bifurcation of the flow from Ladoga could take place, as suggested by K.K. Markov (1934). The formation of cryoturbated flood-plain sands and silts is associated with a decrease in the level below 7-8 $\mathrm{m}$ a.s.l. at the end of the Late Dryas or the beginning of the Early Holocene. As evidenced by buried soils and peat beds, subaerial conditions at these altitudes persisted throughout the entire Holocene up to the maximum of the Ladoga transgression. We assume the tectonic depression of the SW Ladoga territory then followed in the Late Holocene. All this time the waters of the Holocene Baltic palaeobasins not penetrated into the Neva Lowland.

\section{Conclusions}

The data obtained are new evidence of the late glacial age of the Neva River and confirm the conclusions of K.K. Markov (1934) and N.N. Verzilin (1998). The late glacial (pre-) Neva (fluvial system) was formed during the final drainage of the Baltic Ice Lake. When the base level of erosion was reduced in the Yoldia time by downcutting, the water level of this system fell below 7-8 $\mathrm{m}$ a.s.l. already in the Early Holocene.

\section{Acknowledgements}

The authors thank V.Yu. Kuznetsov, head of the Köppen laboratory at SPSU, and A.Yu. Petrov, an employee of the laboratory, for their assistance in revising old dates from sections of the Neva valley; E.M. Bobrovnikova and R.S. Shukhvostov, students of SPSU, for help in field work.

\section{Reference}

Ailio J. 1915. The demographic development of the Ladoga in postglacial time and its relationship to the most temporal colonization. Fenya 38 (3). 157 pp. (in German)

Hyyppä E. 1943. Contributions to the knowledge of the Ladoga and Ancylus transgressions. Bulletin of the Geological Society of Finland 128: 139-178. (in German)

Kuzmin G. F., Kleymenova G.I. et al. 1991. Development of raised bogs of the Leningrad region in the Holocene. Vestnik of Leningrad State University. Series 7: Geology, geography 2: 74-80. (in Russian)

Malakhovsky D.B., Arslanov H.A., Gey N.A. et al. 1993. New data on the Holocene history of the Ladoga Lake. Evolution of natural environments and the current state of the Ladoga Lake geosystem. Russian Geographical Society. Saint Petersburg: 61-73. (in Russian)

Markov K.K., Poretsky V.V., Shlyapina E.V. 1934. On fluctuations in the levels of the Ladoga and Onega Lakes in the postglacial period. Proceedings of The Commission for the study of the Quaternary period IV (1): 71-129. (in Russian)

Vassiljev J., Saare L. 2013. Timing of the Baltic Ice Lake in the eastern Baltic. Bulletin of the Geological Society of Finland 85: 9-18.

Verzilin N.N., Gontarev E.A., Kalmykova N.A. et al. 1998. Lithological and mineralogical features of late- and post glacial deposits of the Neva. Lithology and mineral resources 2: 133-144. (in Russian) 